Research Article

\title{
Preoperative serum albumin level as independent predictor of surgical outcome in acute abdomen
}

\author{
Kanakeswar Bhuyan ${ }^{1 *}$, Smita Das ${ }^{2}$ \\ ${ }^{1}$ Department of Surgery, Gauhati Medical College \& Hospital, Guwahati, Assam, India \\ ${ }^{2}$ Department of Clinical Haematology, Gauhati Medical College \& Hospital, Guwahati, Assam, India
}

Received: 12 December 2015

Accepted: 09 January 2016

\section{*Correspondence:}

Dr. Kanakeswar Bhuyan,

E-mail: kanakbhuyan@gmail.com

Copyright: $\odot$ the author(s), publisher and licensee Medip Academy. This is an open-access article distributed under the terms of the Creative Commons Attribution Non-Commercial License, which permits unrestricted non-commercial use, distribution, and reproduction in any medium, provided the original work is properly cited.

\section{ABSTRACT}

Background: The prognostic implications and significance of hypoalbuminemia after surgical intervention is significant. In this study, we assess the predictive value of preoperative serum albumin level on postoperative morbidity and mortality following surgical intervention in acute abdomen.

Methods: In this retrospective study, Medical records of 110 patients with estimated preoperative serum albumin level undergoing exploratory laparotomy with acute abdominal conditions in a tertiary health care centre were reviewed. Patients with record of preoperative serum albumin level were reviewed. Albumin less than $3.2 \mathrm{~g} / \mathrm{dL}$ was recognized as hypoalbuminemia. Types of surgery, postoperative complications, and mortality rates were collected. The association between preoperative serum albumin level and postoperative morbidity and mortality was assessed.

Results: Preoperative serum albumin level of 3.2g/dl was found in $33(30 \%)$ cases and $77(70 \%)$ patients had same or less than $3.2 \mathrm{~g} / \mathrm{dl}$ albumin. Patients with preoperative serum albumin less than $3.2 \mathrm{~g} / \mathrm{dL}$ had complications in 50 (45.5\%) cases than that of normal preoperative albumin levels (07: 5.5\%; $\mathrm{p}=<0.0001,95 \% \mathrm{CI}=0.119-0.528)$. There was total mortality of $15(14 \%)$. High Mortality of $14(18 \%)$ patients was found in patients with low albumin group. There was $3 \%$ mortality with normal serum albumin level $(\mathrm{P}=<0.362 ; 95 \% \mathrm{CI}=0.029-1.34)$. Skin and soft tissue infections were found in $5(15 \%)$ cases with albumin $>3.2 \mathrm{~g} / \mathrm{dl}$ and 28 cases with less than $3.2 \mathrm{~g} / \mathrm{dl}(\mathrm{p}=<0.397 ; 95 \% \mathrm{CI}=$ $0.17-0.98)$. Chest infections were found in 2 cases (6\%) with $>3.2 \mathrm{~g} / \mathrm{dl}$ serum albumin against 20 cases $(25 \%)$ with less than $3.2 \mathrm{~g} / \mathrm{dl}$. ( $\mathrm{p}=0.0187 ; 95 \% \mathrm{CI}=0.066-0.997)$.

Conclusions: Preoperative hypoalbuminemia is an independent risk factor for postoperative complications after emergency laparotomy.

Keywords: Serum albumin, Surgery, Morbidity, Mortality

\section{INTRODUCTION}

Preoperative risk assessment in surgical patients can be done with some general tests and scores. There are various risk assessment scores that aim to identify morbidity specific outcomes, such as respiratory failure, wound infection or sepsis etc. Risk may be related to planned or emergency procedure and factors within the patient themselves. A higher degree of risk is related to emergency procedure. Higher American Society of Anaesthesiologists (ASA) grading combined with the type of surgery and its urgency has been related to postoperative mortality. ${ }^{1,2}$ There are various preoperative assessment protocols available ${ }^{3,4}$ to identify patients with risk of operative mortality and morbidity. Preoperative nutritional status has been an important factor related to morbidity and mortality. The aim of this study was to assess the predictive value of preoperative serum albumin 
level in postoperative morbidity and mortality following emergency surgery.

\section{METHODS}

In this study medical records of 110 Patients who underwent emergency laparotomy were reviewed retrospectively. Data on demographic characteristics, type of surgery, post-operative complications including mortality were collected. Patients with no significant comorbidity reported and operated within 24 hours were taken into consideration. Laboratory reports containing serum albumin level were taken for the study. Serum albumin level of $3.2 \mathrm{~g} / \mathrm{dL}$ was recognized as standard baseline state in this study. The association between preoperative serum albumin level and postoperative complications including mortality were determined. Statistical analysis was done applying Fisher's exact test using INSTAT software.

\section{RESULTS}

There were $85(77 \%)$ male and $25(22 \%)$ female patients in the study group. Most frequent indication for laparotomy was for perforated duodenal ulcer (43\%) followed by for acute intestinal obstruction (28\%) (Table 1). In $77(70 \%)$ patients the serum albumin found to $3.2 \mathrm{~g} / \mathrm{dL}$ or less. There were skin and soft tissue infections in $33(30 \%)$ cases, respiratory tract infections in $22(20 \%)$ cases and leak and enteric fistula in $2(1.8 \%)$ cases (Table 2). There were 15 mortality $(13.6 \%)$. In 14 cases there were less than $3.2 \mathrm{~g} / \mathrm{dL}$ of S. Albumin (Table 3 ).

Table 1: Indications for emergency laparotomy: No. of patients $(\%)$.

\begin{tabular}{|lll|}
\hline 1. & Indications & Norforated peptic ulcer \\
\hline 2. & $\begin{array}{l}\text { Acute intestinal } \\
\text { obstruction }\end{array}$ & $28(43 \%)$ \\
\hline 3. & $\begin{array}{l}\text { Acute appendicitis } \\
\text { including perforations }\end{array}$ & $20(18 \%)$ \\
\hline 4. & $\begin{array}{l}\text { Incarcerated ventral } \\
\text { hernia }\end{array}$ & $6(0.05 \%)$ \\
\hline 5. & $\begin{array}{l}\text { Small intestinal } \\
\text { perforations }\end{array}$ & $8(0.07 \%)$ \\
\hline
\end{tabular}

Table 2: Morbidity.

\begin{tabular}{|llll|}
\hline Complications & $\begin{array}{l}\text { S. Albumin>3.2g/dL } \\
(\mathbf{3 3} ; \mathbf{3 0} \%)\end{array}$ & $\begin{array}{l}\text { S. Albumin }<3.2 \mathrm{~g} / \mathrm{dL} \\
(\mathbf{7 7} ; \mathbf{7 0} \%)\end{array}$ & $\begin{array}{l}\text { Total }(\mathbf{1 1 0}) \\
\text { p value; 95\% CI }\end{array}$ \\
\hline Skin and soft Tissue infections & $5(15 \%)$ & $28(36 \%)$ & $\begin{array}{l}33(\mathrm{p}<0.0397) \\
95 \% \text { CI }: 0.176-0.984\end{array}$ \\
\hline Respiratory Tract Infections & $2(6 \%)$ & $20(25 \%)$ & $\begin{array}{l}22(20 \%) \\
\text { P<0.0187 } \\
95 \% \text { CI }=0.667-0.997\end{array}$ \\
\hline Fistula & & 2 & $2(1.8 \%)$ \\
\hline Total & $7(5.5 \%)$ & $50(45.5 \%)$ & $\begin{array}{l}57(51.8 \%): \mathrm{p}<0.0001 \\
95 \% \text { CI: } 0.119-0.528\end{array}$ \\
\hline
\end{tabular}

Table 3: Mortality.

\begin{tabular}{|c|c|c|}
\hline $\begin{array}{l}\text { Serum } \\
\text { Albumin level }\end{array}$ & $\begin{array}{l}\text { No. of } \\
\text { Mortality }(\%)\end{array}$ & $\begin{array}{l}\text { P value; } \\
95 \% \mathrm{CI}\end{array}$ \\
\hline$<3.2 \mathrm{G} / \mathrm{dl}$ & $14(18 \%)$ & \\
\hline$>3.2 \mathrm{G} / \mathrm{dl}$ & $01(3 \%)$ & \\
\hline Total & $15(13.6 \%)$ & $<0.362 ; 0.029-1.34$ \\
\hline
\end{tabular}

\section{DISCUSSION}

Albumin, the body's predominant serum-binding protein, has several important functions. ${ }^{5,6}$ It maintains normal plasma colloid oncotic pressure and comprises 50\% of protein content in the body. Albumin transports bilirubin, fatty acids, minerals, trace elements vitamins, hormones and drugs. Serum level of albumin also affects platelet functions. Normal albumin levels indicate adequate kidney and liver and immune functions. Low level of albumin is a marker for malnutrition and associated with increased risk of morbidity and mortality. ${ }^{6}$ The cytokines (TNF, IL-6) released as part of the inflammatory response to physiologic stress (infection, surgery, trauma) can decrease serum albumin by increased vascular permeability, increased degradation and decreased synthesis. The hypoalbuminemia leads to abnormal gastrointestinal malabsorbtion, impaired immunological response and impaired production of albumin and other plasma protiens in the liver. ${ }^{5}$ The outcome of surgery in both emergency and elective is related to status of preoperative serum albumin level though its surgical predictive value was underutilized. ${ }^{5}$

Peptic ulcer perforation constitute a major indication of surgery in this study followed by acute intestinal obstructions with overall mortality and morbidity of $13.6 \% \%$ and $51.8 \%$ respectively. ${ }^{7}$ Risk stratification in 
surgery done following various protocol. ${ }^{3,4}$ In a study of 400 cases undergoing cardiac surgery it was found that hypoalbuminemia was associated with long intensive care and long hospital stay. ${ }^{9}$ In a systematic review comprising more than 29 thousand patients it was observed that shock at admission, preoperative metabolic acidosis, tachycardia, acute renal failure, low serum albumin level, high American Society of Anaesthesiologists score and preoperative delay $>24 \mathrm{~h}$ were associated with poor prognosis. ${ }^{10}$ Serum albumin level as single predicting factor is used in many a study. Hypoalbuminamia was found to be an independent risk factor in surgical site infections following gastrointestinal surgery. ${ }^{8}$ It predicts better in case of sepsis and major infections. ${ }^{5}$ In the present study SSI was found in $15 \%$ cases with $>3.2 \mathrm{~g} / \mathrm{dl}$ albumin whereas the incidence of SSI increased to $36 \%$ with $<3.2 \mathrm{~g} / \mathrm{dl}$ albumin. A meta-analysis of cohort studies found that, with every $10 \mathrm{~g} / \mathrm{L}$ decrease in serum albumin, mortality was increased by $137 \%$ and morbidity increased by $89 \% .^{5,6}$ In the present study patients with $>3.2 \mathrm{~g} / \mathrm{dl}$ albumin has $3 \%$ rate of mortality which increases to $18 \%$ with $<3.2 \mathrm{~g} / \mathrm{dl}$ albumin (Table 3 ). In a study it was found that the in hospital mortality increases from $4 \%$ in normal level of albumin to $14 \%$ in low albumin level. ${ }^{11}$ When ASA grade is compared to Serum Albumin level independently in respect of morality predictions the results came out to be same. ${ }^{11}$ In a similar study it was stated that serum albumin $<3.5 \mathrm{~g} / \mathrm{dl}$ was associated with poor prognosis following abdominal surgery. ${ }^{12}$ In the present study the morbidity was increased from $07(5.5 \%)$ to $50(45.5 \%)$.

\section{CONCLUSION}

Serum albumin level is a good predictor of surgical outcome in emergency abdominal surgery. It is a low cost test and can be used as independent prognostic factor in emergency surgery.

\section{ACKNOWLEDGEMENTS}

Principal cum Chief Superintendent, Gauhati Medical College \& Hospital, Guwahati-781032.

Funding: No funding sources

Conflict of interest: None declared

Ethical approval: The study was approved by the institutional ethics committee

\section{REFERENCES}

1. Boyd O, Jackson N. Clinical review: How is risk defined in high-risk surgical patient management? Critical Care. 2005;9:390-6.
2. Mella J, Biffin A, Radcliffe AG, Stamatakis JD, Steele RJ. Population-based audit of colorectal cancer management in two UK health regions. Colorectal Cancer Working Group, Royal College of Surgeons of England Clinical Epidemiology and Audit Unit. Br J Surg. 1997,84:1731-6.

3. Shoemaker WC, Appel PL, Kram HB, Waxman K, Lee T-S. Prospective trial of supranormal values of survivors as therapeutic goals in high-risk surgical patients. Chest. 1988,94:1176-86.

4. Boyd O, Grounds RM, Bennett ED. A randomized clinical trial of the effect of deliberate perioperative increase of oxygen delivery on mortality in highrisk surgical patients. JAMA. 1993;270:2699-707.

5. Gibbs J, Cull W, Henderson W. Preoperative serum albumin level as a predictor of operative mortality and morbidity: results from the National VA Surgical Risk Study. Arch Surg. 1999;134:36-42.

6. Peralta R. Hypoalbuminemia. Medscape Updated Clinical Reference. 2010. http://emedicine.medscape.com/article/166724. Accessed online from August 18, 2011.

7. Jhabta RS, Attri AK, Kaushik R. Spectrum of perforation peritonitis in India- Review of 504 consecutive cases. W J S. 2006;1:26.

8. Hennessey, Derek BMB, BAO, BCh, BMedSci, MRCSI. Preoperative Hypoalbuminemia is an Independent Risk Factor for the Development of Surgical Site Infection Following Gastrointestinal Surgery: A Multi-Institutional Study: Annals of Surgery. 2010;252(2):325-9.

9. Koertzen M, Punjabi P, Lockwood G. Pre-operative serum albumin concentration as a predictor of mortality and morbidity following cardiac surgery: Perfusion. 2013;28(5):390-4.

10. Møller MH, Adamsen S, Thomsen RW, Møller AM. Preoperative prognostic factors for mortality in peptic ulcer perforation: a systematic review. 2010. doi: 10.3109/00365521003783320.

11. Herrmann FR, MPH, Charles Safran. Serum Albumin Level on Admission as a Predictor of Death, Length of Stay, and Readmission ;Arch Intern Med. 1992;152(1):125-30.

12. Aahlin EK, Tran $\varnothing$ G, Johns N. Risk factors, complications and survival after upper abdominal surgery: a prospective cohort study. BMC Surg. 2015;15:83.

Cite this article as: Bhuyan K, Das S. Preoperative serum albumin level as independent predictor of surgical outcome in Acute Abdomen. Int Surg J 2016;3:277-9. 